\title{
LMFBR Fuel Pin Cladding \\ Transient Performance \\ Capabilities: An Analysis of FCIT Data
}

Prepared for

The U.S. Nuclear Regulatory Commission Under Related Services Contract TDO 699 to the Prime Contract E(45-1): 1830 with the Energy Research and Development Administration

by

John W. Wald

Ira S. Levy

March 1976 
Inis report was prepared as an account of work sponsored by the Linited States Covernment. Vether the

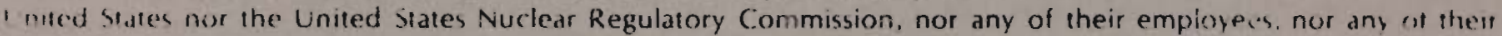
rontrators. subcontractors, or the:r emplojees. makes any warranty, express or implied or dssumes an; lega! iabi!i, ur responsibility tor the accuracy, completeness or usefulness of any information, apparatus, produrt or procest riscicsed. or represents that its use would not infringe privately owned rights.

\section{PACIFIC NORTHWEST LABORATORY}

operated by

BATTELLE

for the

U.S. ENERGY RESEARCH AND DEVELOPMENT ADMINISTRATION

Under Contract E(45-1)-1830

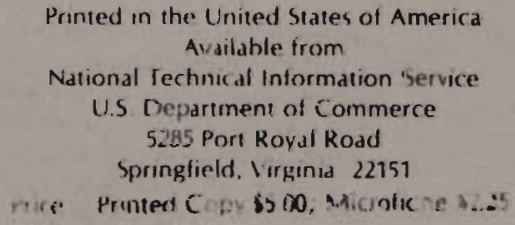


BNWL -2041

$\mathrm{NRC}-1$

\section{3}

LMFBR FUEL PIN CLADDING

TRANSIENT PERFORMANCE CAPABILITIES:

AN ANALYSIS OF FCTT DATA.

Prepared for

The U.S. Nuclear Regulatory Commission Under Related Services Contract TD0 699 to the Prime Contract E(45-1): 1830 with the Energy Research and Development Administration

by John W. Wald

Ira S. Levy

March 1976

Battelle

Pacific Northwest Laboratories

Richland, Washington 99352 


\section{$\underline{\text { ABSTRACT }}$}

Fuel Cladding Transient Tester (FCTT) data, from experiments being performed at Westinghouse Hanford Company - Hanford Engineering Development Laboratories (HEUL), has been evaluated to establish a basis for assessing the margin of safety provided by the fuel pin transient performance design criteria for Transient Overpower events (TOP).

These criteria, as presented in the Clinch River Breeder Reactor Plant Preliminary Safety Analysis Report, describe cladding temperature limits from PPS trip settings, residual strength values utilized in CDF rod integrity analyses, and incremental cladding strain limits for transients. The FCTT data analyses indicate that:

- Most failures occur below the cladding temperature limits for upset $\left(1450^{\circ} \mathrm{F}\right)$ and emergency $\left(1600^{\circ} \mathrm{F}\right)$ events.

- Residual strength values less than those used in the CDF analysis (0.736 to 0.864 of unirradiated values) were observed (and for fluences less than one-third of goal exposures).

- Failures with incremental strain values below the design limit $(0.1 \%)$ were observed and the scatter in these strain data is large. 


\section{TABLE OF CONTENTS}

ABSTRACT. . . . . . . . . . . . . . . . . . . . . .

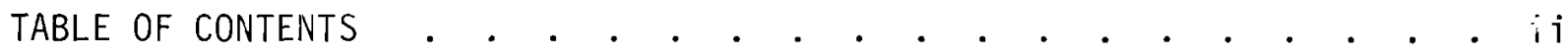

LIST OF TABLES. . . . . . . . . . . . . . . . . . . .

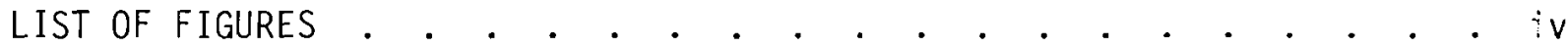

1.0 INTRODUCTION . . . . . . . . . . . . . . . . . . . . . 1

2.0 FCTT EXPERIMENTAL PROCEDURE AND DATA . . . . . . . . . . . . . 2

3.0 DATA ANALYSIS RELATIVE TO CRBRP DESIGN CRITERIA . . . . . . . . 4

3.1 Temperature . . . . . . . . . . . . . . . . 4

3.2 Strength . . . . . . . . . . . . . . . . . . 5

3.3 Ductility. . . . . . . . . . . . . . . . 6

4.0 DISCUSSION AND CONCLUSIONS . . . . . . . . . . . . . . . . 7

4.1 FCTT Data Analysis Relative to CRBRP Design Criteria. . . . 7

4.2 FCTT Analysis Relative to Fuel Rod Failure Criteria and Failure Location Studies. . . . . . . . . . . . 8

REFERENCES . . . . . . . . . . . . . . . . . . . . . 9 


\section{LIST OF TABLES}

Table

I-A Irradiated Cladding Burst Test Results from NUMEC and PNL Pins - Fueled Region Data. . . . . . . 10

I-B Irradiated Cladding Burst Test Results from NUMEC and PNL Pins - Plenum Region Data. . . . . . . . 11

II Unirradiated Clading Burst Test Results . . . . . . 12 


\section{LIST OF FIGURES}

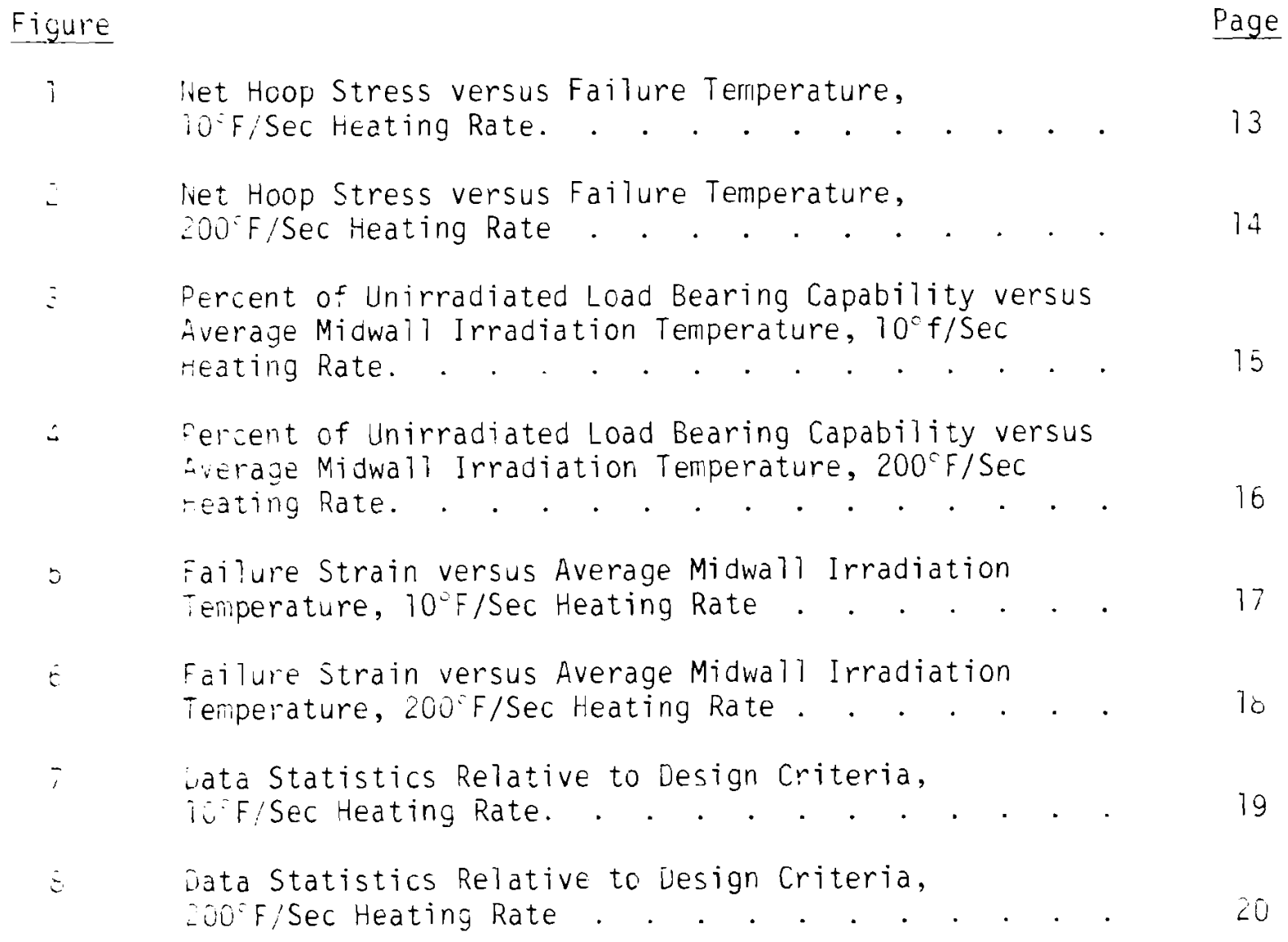




\subsection{INTRODUUCTION}

This report is the result of work performed under Subtask B, Cladding Uesign Bases Evaluation, of Task 2: LMFBR Fuel and Control Rod Behavior, of the Fuel Rod Integrity Project. The work was performed under the joint sponsorship of the Uivisions of Systems Safety and Project Management, Cffice of Nuclear Reactor Regulation, U.S. Nuclear Regulatory Commission. The purpose of this report is to analyze recently available fuel pin transient performance data to satisfy two requirements:

A) Provide NRC with a basis for assessing the margin of safety provided by the fuel pin transient performance design criteria for Transient Overpower (TOP) events presented in the Clinch River Breeder Reactor Plant Preliminary Safety Analysis Report (CRBRP PSAR) ${ }^{1}$.

B) Provide input to fuel rod failure criteria and failure location analyses being performed in other facets of this NRC project (Subtask D).

The fuel pin transient performance data to be analyzed are from Fuel cladding Transient Tester (FCTT) experiments being performed at the Westinghouse Hanford Company - Hanford kngineering Uevelopment Laboratory (HEDL). 2, 3 


\subsection{FCTT EXPERIMENTAL PROCEUURE AND DATA}

\subsection{Experimental Procedure}

The FCTT system at HEuL was specifically designed to perform transient tests on reactor cladding. In this apparatus, controlled rapid specimen heating was provided by appropriately designed induction heating coils. Pressurization was accomplished with a low-volume argon gas system. The sma11 gas volume in the specimen and FCTT system is intended to make the failure event more prototypic of a fuel-column cladding failure than would be found in a conventional burst test. ${ }^{3}$

The experimental concept used in these FCTT tests was to apply a predetermined stress to the fuel pin, heat it under controlled heating rates to failure, and then experimentally determine the failure temperature and incremental failure strain. Heating rates of $10^{\circ} \mathrm{F} / \mathrm{sec}$ and $200^{\circ} \mathrm{F} / \mathrm{sec}$ were selected as representative of the range of interest of transient overpower conditions for the Fast Flux Test Facility (FFTF). The two heating rates produce different amounts of thermal recovery and annealing, as well as impose different cladding strain rates, as anticipated in the various reactor transients.

The experimental procedure for the FCTT tests were as follows:

A) The specimen was pressurized to approximately $80 \%$ of desired initial pressure while the specimen was at room temperature.

B) The specimen was heated to the initial temperature of $700^{\circ} \mathrm{F}$ and the pressure was adjusted to the exact level desired.

C) After the initial temperature and pressure were obtained, the specimen was heated at $10^{\circ} \mathrm{F} / \mathrm{sec}$ or $200^{\circ} \mathrm{F} / \mathrm{sec}$ until it failed.

The specimens used in the FCTT studies were standard 20\% cold-worked 316 stainless steel, 0.230 inch 0.D. X 0.015 inch wall $\times 2.45$ inch nominal length. Specimens were taken from unirradiated lots as well as from fuel pins irradiated in EBR-II. 


\section{2 vata Base}

The data base available to date from FCTT on irradiated ${ }^{2}$ and unirradiated 3 specimens are presented in Tables $I$ and II, respectively. Since the CRBRP fuel pin performance criteria and accident scenarios relate to pin failure in the core (fueled) region of the fuel pin, data from the fueled and plenum (unfueled) regions of the irradiated pins are presented separately in this report in Tables IA and IB, respectively.

Fuel column height in EBR-II runs was 13.5 inches; therefore, all sections taken above this distance from the bottom of the fuel, as well as those sections taken below the fuel bottom, are considered plenum. All samples were taken from either iNUMEC-F, PNL-10, or PNL-11 pins.

Specimen wastage is noted in Tables IA and IB; these are due to sodium corrosion on the O.D., fuel attack on the I.D., and wear marks on the O.D. from the wire wrap. These data will be denoted by an asterisk but will be given full weight when they are graphically presented later in this report since there is no reason to consider them as representing anything other than prototypic of fuel rod performance to be expected in CRBRP and commercial reactors. 


\subsection{UATA ANALYSIS RELATIVE TO CRPRP DESIGN CRITERIA}

The CRBRP PSAR presents three criteria relative to fuel pin TOP performance: strength, temperature, and cladding strain. The analyses here will deal with the FCTT data relative to these criteria.

\subsection{Temperature}

\subsubsection{PSAR Presentations}

The temperatures of $1450^{\circ} \mathrm{F}$ and $1600^{\circ} \mathrm{F}$ are utilized in the PSAR to describe the maximum cladding temperature for upset and emergency events, respectively, for any extended period of time, allowed by Plant Protection System trip subsystems and their settings. 4,5

\subsubsection{FCTT Data Analysis}

Figures 1 and 2 illustrate the relationship between plenum and fueled data for net sectional hoop stress versus failure temperature. The solid line in each figure represents the unirradiated data appearing in Table II. As indicated by the banded regions in these figures, the performance of specimens from fueled and plenum regions differ. While the plenum region's behavior tended to be quite similar to that of the unirradiated material, the fueled region material indicated, overall, a decrease in failure temperature over the unirradiated for given values of failure stress. This trend tended to be most apparent in the $10^{\circ} \mathrm{F} / \mathrm{sec}$ rate (Figure 1 ), where reductions in failure temperature approached $450^{\circ} \mathrm{F}$ at higher temperatures and lower stresses. For $200^{\circ} \mathrm{F} / \mathrm{sec}$ (Figure 2), a lesser reduction in failure temperature for a given failure stress occurs; the maximum differential here is about $100^{\circ} \mathrm{F}$.

For both ramp rates, failure temperatures of the fueled specimens occur well below $1600^{\circ} \mathrm{F}$, with failures observed at temperatures as $10 \mathrm{w}$ as $1005^{\circ} \mathrm{F}$. At $10^{\circ} \mathrm{F} / \mathrm{sec}, 100 \%$ of the fueled specimen failed below $1450^{\circ} \mathrm{F}$; at $200^{\circ} \mathrm{F} / \mathrm{sec}$, $67 \%$ failed below $1600^{\circ} \mathrm{F}$ and $53 \%$ failed below $1450^{\circ} \mathrm{F}$. 


\subsection{Strength}

\subsubsection{PSAR Presentation}

The Cumulative Mechanical vamage Function (CDF) ${ }^{6}$ monitors clad integrity through steady-state and transient operation. CDF includes a function, $R_{\sigma}$, describing the relative residual strength of the unirradiated cladding subjected to prior strain that is utilized in the PSAR fuel rod integrity analysis. ${ }^{7}$ Relative residual strengths for unirradiated cladding of from 0.736 to 0.864 were used to evaluate CDF. The PSAR states that a preliminary analysis indicates that the fuel rod design life can be achieved with a 74 day margin in 1 ife. ${ }^{8}$

\subsubsection{FCTT Data Analysis}

Utilizing data in Tables IA and II, irradiated fuel rod cladding transient strength has been examined in terms of percent of unirradiated load bearing capability. This quantity, which is defined as the ratio of irradiated failure stress to unirradiated failure stress, taken at similar failure temperatures, is equivalent in concept to the "relative residual strength" used in the PSAR. Since hoop stress is an experimental input variable in FCTT, failure temperature will become the dependent variable; and, for a given failure temperature, the ratio of stress at failure of irradiated specimens to that for unirradiated specimens will reflect the fraction of unirradiated load bearing capability remaining in the irradiated specimens.

Figures 3 and 4 present data for percent of unirradiated load bearing capability versus steady-state midwall irradiation temperature. These data indicate decreased load-bearing capability as a result of irradiation and temperature ramp-rate. The low temperature-ramp $\left(10^{\circ} \mathrm{F} / \mathrm{sec}\right)$ reduces irradiated specimen load-bearing capability to values as $10 \mathrm{w}$ as $40 \%$ of unirradiated values, with the best straignt 1 ine ranging from $50-70 \%$ of unirradiated values. The higher temperature-ramp $\left(200^{\circ} \mathrm{F} / \mathrm{sec}\right)$ resulted in a lesser reduction in irradiated specimen load bearing capability than that seen for the $10^{\circ} \mathrm{F} / \mathrm{sec}$ temperature-ramp. While reductions to values as low as $45 \%$ were also observed, the best straight 1 ine ranged from $95-110 \%$ of unirradiated values. 


\subsection{Ductility}

\subsubsection{PSAR Presentation}

The allowed incremental strain during all operational (upset) and worst minor incident (emergency) events at a 2-to-1 stress biaxiality is a maximum of $0.1 \%$. (The total allowed strain for steady-state and transient operations is less than $0.3 \%,{ }^{9}$ while that allowed for steady-state operation only is less than $0.2 \%{ }^{10}$ )

\section{3 .2 FCTT Analysis}

Data in Tables IA and IB were analyzed in terms of the steady-state midwall irradiation temperature to assess the incremental failure strain during transients relative to axial rod position; these data are presented in Figures 5 and 6 . The lower failure strains of the fueled regions of the rod is evident at both ramp-rates for a 11 midwall irradiation temperatures. Least squares linear fit of the fueled data are presented for the two ramp rates in Figures 7 and 8 . At $10^{\circ} \mathrm{F} / \mathrm{sec}$ (Figure 7 ), a number of data points can be seen to fall below the $0.1 \%$ additional strain allowed during transient. Moreover, the lower limit established by the deviation of the data about the 1 ine indicates that failures will occur below $0.1 \%$ additional strain at steady-state irradiation temperatures as high as $1000^{\circ} \mathrm{F}$ at these fluence levels.

At the $200^{\circ} \mathrm{F} / \mathrm{sec}$ heating rate (Figure 8 ), the least squares fit indicates that higher strain values are experienced for all midwall irradiation temperatures; however, the data scatter is larger as we11. A $95 \%$ confidence limit analysis indicates that failure could be expected to occur below the $0.1 \%$ additional strain limit up through an $1100^{\circ} \mathrm{F}$ steady-state irradiation temperature at these fluence levels (zero added strain is within the lower $1 \mathrm{imit).}$ 


\subsection{DISCUSSION_AINU CONCLUSIONS}

\subsection{FCTT Data Analysis Relative to CRBRP Design Criteria}

The FCTT data indicate reason to question with the CRBRP fuel rod design performance criteria. These criteria have been compared with experimentallydetermined cladding properties and variances have been noted.

\subsubsection{Temperature}

The majority of specimens failed at temperatures below those described in the PSAR as the maximum expected to be allowed for upset and emergency events $\left(1450^{\circ} \mathrm{F}\right.$ and $1600^{\circ} \mathrm{F}$ respectively). The basis for the protection system setpoints should be examined.

\section{1 .2 Strength}

Percent of unirradiated load bearing capability of fuel rods after irradiation to only $1 / 3$ goal CRBRP exposure, ${ }^{*}$ is significantly less than the "residual strength" values used to verify CDF, and upon which a fuel rod design life was predicted to be achieved with a 74-day margin in life. Moreover, since continued residence time of fuel pins in-reactor towards relevant cladding fluences would be expected to cause further degradation to the cladding by irradiation and sodium- and fuel-attack, further reductions in load-bearing capabilities would be expected. This would increase the disparity between experimental results and those values used in the CDF analysis of fuel rod design life. The basis for these residual strength values should be examined.

\section{1 .3 Ductility}

At $10^{\circ} \mathrm{F} / \mathrm{sec}$, failures occur at less than the specified transient strain limit ( $0.1 \%$ additional strain) for steady-state rod temperatures up to $900^{\circ} \mathrm{F}$ and the lower $95 \%$ confidence limit indicates failures can be expected at less than $0.1 \%$ strain up through the $1000^{\circ} \mathrm{F}$ irradiation temperature. At $200^{\circ} \mathrm{F} / \mathrm{sec}$, the lower $95 \%$ confidence limit indicates failures can be expected below $0.1 \%$ strain for steady-state rod temperatures up through $1000^{\circ} \mathrm{F}$. These data are for low cladding exposures ( $\leq 1 / 3$ goal CRBRP burnups $\left.{ }^{*}\right)$. The basis for the $\leq 0.1 \%$ transient strain limit should be examined. 


\subsection{FCTT Analysis Relative to Fuel Rod Failure Criteria and Failure Location Studies}

The analysis provides an independent data base for a "strain-to-failure" fuel rod failure criteria through Figures 7 and 8 . Best straight 1 ines and limit bands are provided. Failure strain varies with axial location at the $10^{\circ} \mathrm{F} / \mathrm{sec}$ heating ramp rate but not at $200^{\circ} \mathrm{F} / \mathrm{sec}$; the magnitude of the failure strains are larger at the $200^{\circ} \mathrm{F} / \mathrm{sec}$ ramp rate. 


\section{REFERENCES}

1. Clinch River Breeder Reactor Plant - Preliminary Safety Analysis Report, issued by Project Management Company, April 1975.

2. C. W. Hunter, G. D. Johnson and R. L. Fish, "Mechanical Properties During Simulated Overpower Transients of Fast Reactor Cladding Irradiated from 700-1100%," HEUL-TME 75-28, September 1975.

3. C. W. Hunter, R. L. Fish and J. J. Holmes, "Mechanical Properties of Unirradiated Fast Reactor Cladding During Simulated Overpower Transients," HEDL-SA 770, October 1974.

4. CRBRP - PSAR, p. 15.1-74.

5. ibid, p. 4.2-42.

6. ibid. p. 15.1-50.

7 ibid, p. 15.1-54 through 15.1-62

8. ibid, p. 4.2-45

9. ibid, p. 4.2-6

10. ibid, p. 4.2-5 
TABLE I-A. Irradiated Cladding Burst Test Results from NUMEC and PNL Pins - Fueled Region Data

\begin{tabular}{|c|c|c|c|c|c|c|c|c|c|c|c|c|c|}
\hline \multicolumn{2}{|c|}{$\begin{array}{l}\text { Specinen } \\
\text { 1.0. Number } \\
\end{array}$} & $\begin{array}{l}\text { Distance Above } \\
\text { Fuel Bottom, in. }\end{array}$ & \multicolumn{2}{|c|}{$\begin{array}{l}\text { Midwall } \\
\text { Temperature of }\end{array}$} & \multicolumn{2}{|c|}{$\begin{array}{l}\text { Fluence }[\mathrm{E}>1 \mathrm{HeV}] \\
\left.\text { ot } \times 10^{2} \mathrm{n} / \mathrm{cm}^{2}\right]\end{array}$} & \multirow[t]{2}{*}{$\begin{array}{c}\text { Gas } \\
\text { Pressure, PSI }\end{array}$} & \multirow[t]{2}{*}{$\begin{array}{l}\text { Transient } \\
\text { Heating Rate, " } \mathrm{F} / \mathrm{sec}\end{array}$} & \multirow[t]{2}{*}{$\begin{array}{l}\text { Nominal Hoop } \\
\text { Stress, K.SI }\end{array}$} & \multirow[t]{2}{*}{$\begin{array}{l}\text { Maxinum Cladding } \\
\text { Hastage, mils }\end{array}$} & \multirow[t]{2}{*}{$\begin{array}{l}\text { Net Section } \\
\text { Hoop Stress, KS1 }\end{array}$} & \multirow[t]{2}{*}{$\begin{array}{l}\text { Diametral Failure } \\
\text {-Strain, } x\end{array}$} & \multirow[t]{2}{*}{$\begin{array}{l}\text { Failure } \\
\text { Iemperature, }\end{array}$} \\
\hline NUMEC - F & & & & & & & & & & & & & \\
\hline $\begin{array}{l}N-005: \\
N-035: \\
N-027: \\
N-235: \\
N-035: \\
N-35: \\
N-159: \\
N-027: \\
N-005:\end{array}$ & $\begin{array}{l}D \\
B \\
D \\
C \\
C \\
D \\
F \\
D \\
F \\
B\end{array}$ & $\begin{array}{c}4.5-7.0 \\
(-0.5)-2.0 \\
2.0=4.5 \\
2.0=4.5 \\
4.5=7.0 \\
9.5=12.0 \\
2.0=4.5 \\
7.0=9.5 \\
(-0.5)-2.0\end{array}$ & $\begin{array}{l}825=870 \\
700=785 \\
785=840 \\
785=850 \\
850=910 \\
960=1000 \\
785=845 \\
900=955 \\
700=775\end{array}$ & $\begin{array}{l}(848) \\
(743) \\
(813) \\
(818) \\
(880) \\
980) \\
(815) \\
(828) \\
(738)\end{array}$ & $\begin{array}{l}3.1=3.2 \\
2.0=2.7 \\
2.6=3.0 \\
2.7=3.1 \\
3.1=3.2 \\
2.9=2.4 \\
2.5=3.0 \\
3.1=2.8 \\
2.0=2.7\end{array}$ & $\left.\begin{array}{l}(3.05) \\
2.35 \\
(2.80) \\
2.90 \\
3.05 \\
(2.65) \\
(2.75) \\
(2.95 \\
(2.35\end{array}\right)$ & $\begin{array}{r}4,000 \\
6,000 \\
6,000 \\
6,000 \\
6,000 \\
6,000 \\
10,000 \\
10,000 \\
13,500\end{array}$ & $\begin{array}{l}10 \\
10 \\
10 \\
10 \\
10 \\
10 \\
10 \\
10 \\
13\end{array}$ & $\begin{array}{l}28.8 \\
43.2 \\
43.2 \\
43.2 \\
43.2 \\
43.2 \\
72.0 \\
72.0 \\
97.2\end{array}$ & $\begin{array}{l}0 \\
0.8 \\
0.4 \\
0 \\
0 \\
0.5 \\
0.1 \\
0.2 \\
0\end{array}$ & $\begin{array}{l}28.8 \\
45.6 \\
44.4 \\
43.2 \\
43.2 \\
44.7 \\
72.5 \\
73.0 \\
97.2\end{array}$ & $\begin{array}{l}0.15 \\
0.06 \\
0.15 \\
0.16 \\
0.08 \\
0.13 \\
0.13 \\
0.35 \\
0.25\end{array}$ & $\begin{array}{l}1325 \\
1005 \\
1180 \\
1170 \\
1125 \\
1175 \\
1020 \\
1175 \\
1040\end{array}$ \\
\hline \multicolumn{14}{|c|}{ PNL-10, PNL-11 } \\
\hline $\begin{array}{l}\text { 10-63: } \\
10-23: \\
10-63: \\
11-20 R: \\
11-12:\end{array}$ & $\begin{array}{l}G \\
I \\
M \\
L \\
G\end{array}$ & $\begin{array}{l}2.0-4.5 \\
4.0-6.5 \\
8.94-11.44 \\
8.75-11.25 \\
3.0-5.5\end{array}$ & $\begin{array}{l}770-855 \\
825-885 \\
890-925 \\
925=965 \\
797=840\end{array}$ & $\begin{array}{l}(813) \\
(855) \\
(908) \\
(945) \\
(819)\end{array}$ & $\begin{array}{l}3.6-4.1 \\
3.8-4.0 \\
4.1=3.4 \\
2.4=2.0 \\
2.3=2.5\end{array}$ & $\begin{array}{l}(3.85) \\
(3.90) \\
(3.75) \\
(2.20) \\
(2.40)\end{array}$ & $\begin{array}{r}4,000 \\
4,000 \\
4,000 \\
6,000 \\
10,000\end{array}$ & $\begin{array}{l}10 \\
10 \\
10 \\
10 \\
10\end{array}$ & $\begin{array}{l}28.8 \\
43.2 \\
43.2 \\
43.2 \\
72.0\end{array}$ & $\begin{array}{l}0(i) \\
0(1) \\
2.7(2) \\
0 \\
0\end{array}$ & $\begin{array}{l}28.8 \\
43.2 \\
43.2 \\
43.2 \\
72.0\end{array}$ & $\begin{array}{l}0.04 \\
0.05 \\
0.21 \\
0.17 \\
0.12\end{array}$ & $\begin{array}{l}1395 \\
1095 \\
1105 \\
1165 \\
1070\end{array}$ \\
\hline \multicolumn{14}{|l|}{ NUMEC-F } \\
\hline $\begin{array}{l}\text { N-005: } \\
N-005: \\
N-035: \\
N-159: \\
N-035: \\
N-070 \\
N-027: \\
N-027: \\
N-070: \\
N-035: \\
N-027:\end{array}$ & $\begin{array}{l}E \\
C \\
\text { E } \\
C \\
H \\
D \\
E \\
H \\
N \\
N \\
H \\
C\end{array}$ & $\begin{array}{c}7.0-9.5 \\
2.0-4.5 \\
7.0-9.5 \\
(-0.5)-2.0 \\
12.5-15.0 \\
0.5-3.2 \\
4.5-7.0 \\
12.0-14.5 \\
12.0-14.5 \\
12.5-15.0 \\
(-0.5)-2.0\end{array}$ & $\begin{array}{l}870-910 \\
775-825 \\
910-960 \\
700-785 \\
945-920 \\
750-812 \\
840-900 \\
990-975 \\
1000-990 \\
1000-990 \\
700-785\end{array}$ & $\begin{array}{l}(890) \\
(8900) \\
(935) \\
(7933) \\
(935) \\
(781) \\
(870) \\
(983) \\
(995) \\
(995) \\
(743)\end{array}$ & $\begin{array}{l}3.2-2.9 \\
2.7=3.1 \\
3.2=2.9 \\
1.8=2.5 \\
2.2=1.6 \\
2.1=2.7 \\
3.0=3.1 \\
2.3=1.6 \\
2.2=1.6 \\
2.2=1.6 \\
1.9=2.6\end{array}$ & $\begin{array}{l}(3.05) \\
(2.90) \\
(3.05) \\
(2.15 \\
(1.90) \\
(2.40) \\
(3.05) \\
(1.95) \\
(1.90) \\
(1.90) \\
(1.25)\end{array}$ & $\begin{array}{r}2,500 \\
4,000 \\
4,000 \\
6,000 \\
6,000 \\
10,000 \\
10,000 \\
10,000 \\
10,000 \\
10,000 \\
13,500\end{array}$ & $\begin{array}{l}200 \\
200 \\
200 \\
200 \\
200 \\
200 \\
200 \\
200 \\
200 \\
200 \\
200\end{array}$ & $\begin{array}{l}18.0 \\
28.6 \\
28.8 \\
43.2 \\
43.2 \\
72.0 \\
72.0 \\
72.0 \\
72.0 \\
72.0 \\
97.2\end{array}$ & $\begin{array}{l}0 \\
0 \\
0 \\
0.2 \\
0 \\
0 \\
0 \\
2.2 \\
3.9 \\
0.8 \\
0\end{array}$ & $\begin{array}{l}18.0 \\
28.8 \\
28.8 \\
43.8 \\
43.2 \\
72.0 \\
72.0 \\
84.4 \\
97.3 \\
76.1 \\
97.2\end{array}$ & $\begin{array}{l}0.80 \\
0.40 \\
0.25 \\
0.30 \\
0.18 \\
0.20 \\
0.40 \\
0.70 \\
0.29 \\
0.22 \\
0.40\end{array}$ & $\begin{array}{l}1940 \\
1670 \\
1625 \\
1520 \\
1490 \\
1210 \\
1310 \\
1205 \\
1070 \\
1140 \\
1120\end{array}$ \\
\hline \multicolumn{14}{|c|}{ PNL-10, PNL-11 } \\
\hline $\begin{array}{l}10-63: \\
10-23: \\
10-23: \\
11-12:\end{array}$ & $\begin{array}{l}0 \\
H \\
M \\
K\end{array}$ & $\begin{array}{l}12.44-14.94 \\
1.5-4.0 \\
8.5=11.0 \\
7.5-10.0\end{array}$ & $\begin{array}{l}940-920 \\
770-825 \\
925-980 \\
870-905\end{array}$ & $\begin{array}{l}(930) \\
(798) \\
(953) \\
(888)\end{array}$ & $\begin{array}{l}3.1=2.5 \\
3.2=3.8 \\
3.9=3.4 \\
2.5=2.2\end{array}$ & $\begin{array}{l}(2.80) \\
(3.50) \\
(3.65) \\
(2.35)\end{array}$ & $\begin{array}{r}2,500 \\
4,000 \\
4,000 \\
10,000\end{array}$ & $\begin{array}{l}200 \\
200 \\
200 \\
200\end{array}$ & $\begin{array}{l}18.0 \\
28.8 \\
28.8 \\
72.0\end{array}$ & $\begin{array}{l}0 \\
0 \\
2.5 \\
0 \\
0\end{array}(1,2)$ & $\begin{array}{l}18.0 \\
28.8 \\
28.8 \\
72.0\end{array}$ & $\begin{array}{l}0.96 \\
0.65 \\
0.20 \\
0.17\end{array}$ & $\begin{array}{l}1980 \\
1770 \\
1400 \\
1230\end{array}$ \\
\hline
\end{tabular}

NOTES:

(1) Sample Sectioned but did not find failure site. 
TABLE I-B. Irradiated Cladding Burst Test Results from NUMEC and PNL Pins - Plenum Region Data

Specimen
D. Distance Above
Fuel Bottom, in

Fluence $[\mathrm{E}>$, I MeV]

Gas
Transient
Pressure, $D S I$ Heating

Nominal Hoop Maximum Cladding

NUMEC-F

N-035: I $\quad 15.0-17.5$

$N-005:$
$N-035:$
$N-035:$

$15.0-17.5$
$33.6=36.1$
$20.0-22.5$

990
920

$\begin{array}{lll}1.6 & -1.2 \quad(1.40) & 4.000 \\ 0.1 & 0.000 & 0\end{array}$

4,000
6,000
6,000
6,000

10
10
10
10

$\begin{array}{ll}28.8 & 0 \\ 43.2 & 5.5 \\ 43.2 & 0 \\ 43.2 & 0\end{array}$

Net Section

Diametral Failure

Fal?ure

$\begin{array}{ll}\mathrm{N}-035: & \mathrm{J} \\ \mathrm{PNL}-30, \mathrm{PNL}-11 & \end{array}$

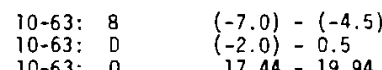

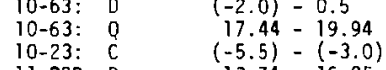

$\begin{array}{lll}990 & 0.8-0.5 & (0.65 \\ 900 & 1.2=0.8 \quad(1.00\end{array}$

$\begin{array}{llll}700 & 1.0-1.5 & (1.25) & 6,000 \\ 700 & 2.1=3.1 & (2.60) & 6,000 \\ 920 & 1.7-1.2 & (1.45) & 6,000\end{array}$

11-20R: $P$

$\begin{aligned}(-5.5) & -(-3.0) \\ 13.74 & -16.25\end{aligned}$

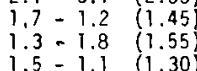

10,000
10,000

NUMEC-F

960

10
10,000

$\begin{array}{ll}43.2 & 0 \\ 43.2 & 0.7(2) \\ 43.2 & 2.1 \\ 72.0 & 0 \\ 72.0 & 0\end{array}$

$\begin{array}{lll}975 & 1.7-1.2 & (1.45) \\ 920 & 0.8-0.6 & (0.70) \\ 920 & 0.2-0.8 & (0.00)\end{array}$

$14.5-17.0$
$20.0-22.5$

$17.5-22.5$
$33.6=36.1$

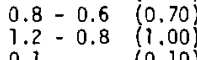

N-005:

$33.0=33.6$
$31.1=33.6$
$15.0=17.2$

2.500
4,000

990
990

$0.1-0.8$
$0.2-0.1$
$1.5-1.1(0.15)$
$1.30)$

4,000
4,000
6,000
6,000

$\begin{array}{ll}18.0 & 0 \\ 28.8 & 5.2 \\ 28.8 & 4.8 \\ 28.8 & 0 \\ 43.2 & 0 \\ 43.2 & 0\end{array}$

$\begin{array}{lll}700 & 1.5-2.1 & (1.80) \\ 995 & 2.4-1.8 & (2.10) \\ 919 & 2.5-1.7 & (2.10) \\ 700 & 0.8-1.3 & (1.05) \\ 700 & & \end{array}$

$(-4.5)-(-2.0)$
$13.94=16.44$

4,000

$14.94=17.44$
$(-8.0)-(-5.5)$

700

$0.8-1.3$
$1.8-2.6 \quad(2.05)$

6,000
10,000
13,500

13,500
13,500

10
10
10
10
10

200
200
200
200
200
200

$\begin{array}{ll}28.8 & 0 \\ 43.2 & 4.4 \\ 72.0 & 1.9 \\ 97.2 & 0 \\ 97.2 & 0\end{array}$

28.8
68.2
43.2
43.2

43.2
45.3
50.2
72.0
72.0

18.0
44.1
38.6
28.8
43.2
43.2

28.8
55.9
82.5
97.2
97.2

$\begin{array}{ll}0.40 & 1630 \\ 0.23 & 1420 \\ 0.70 & 1505 \\ 1.00 & 1540 \\ & \\ 0.65 & 1540 \\ 0.30 & 1330 \\ 0.30 & 1485 \\ 0.54 & 1340 \\ 0.65 & 1325 \\ & \\ 0.90 & 1920 \\ 0.80 & 1705 \\ 0.60 & 1710 \\ 0.70 & 1820 \\ 0.60 & 1600 \\ 0.70 & 1680 \\ & \\ 0.56 & 1890 \\ 0.35 & 1550 \\ 0.26 & 1270 \\ 0.69 & 1230 \\ 0.54 & 1320\end{array}$

NOTES:

(1) Estimated. were not wastage. 
Table II Unirradiated Cladding Burst Test Results

\begin{tabular}{|c|c|c|c|c|c|}
\hline $\begin{array}{c}\text { Speciman } \\
\text { Identification }\end{array}$ & $\begin{array}{c}\text { Gas } \\
\text { Pressure } \\
\text { psi }\end{array}$ & $\begin{array}{c}\text { Hoop } \\
\text { Stress } \\
\text { ksi } \\
\end{array}$ & $\begin{array}{c}\text { Transient } \\
\text { Heating Rate } \\
{ }^{\circ} \mathrm{F} / \mathrm{sec} \\
\end{array}$ & $\begin{array}{c}\text { Diametral } \\
\text { Strain } \\
\% \\
\end{array}$ & $\begin{array}{l}\text { Termination } \\
\text { or Failure } \\
\text { Temp., }{ }^{\circ} \mathrm{F}\end{array}$ \\
\hline 28 & 180 & 1.30 & 10 & $0.7^{\star}$ & $2385 *$ \\
\hline 30 & 450 & 3.24 & 10 & $2.4^{\star}$ & $2300 *$ \\
\hline 67 & 1,000 & 7.20 & 10 & $6.3^{\star}$ & 2090 * \\
\hline 52 & 1,000 & 7.20 & 10 & 6.7 & 2045 \\
\hline & 1,000 & 7.20 & 10 & $8.2^{\star}$ & $2055 *$ \\
\hline 53 & 1,000 & 7.20 & 10 & 4.3 & 2030 \\
\hline & 1,000 & 7.20 & 10 & $7.4^{*}$ & $2050 *$ \\
\hline 68 & 2,500 & 18.0 & 10 & $7.4^{\star}$ & $1870 *$ \\
\hline 48 & 2,500 & 18.0 & 10 & 4.2 & 1835 \\
\hline & 2,500 & 18.0 & 10 & $8.2^{\star}$ & $1860^{\star}$ \\
\hline 50 & 2,500 & 18.0 & 10 & 2.6 & 1820 \\
\hline 51 & 2,500 & 18.0 & 10 & 1.3 & 1800 \\
\hline 49 & 2,500 & 18.0 & 10 & 0.60 & 1760 \\
\hline 59 & 4,000 & 28.0 & 10 & $6.6^{\star}$ & $1720^{\star}$ \\
\hline 69 & 4,000 & 28.8 & 10 & $5.2^{\star}$ & $1720 *$ \\
\hline 80 & 4,000 & 28.8 & 10 & $5.0^{*}$ & $1710 *$ \\
\hline 47 & 6,000 & 43.2 & 10 & $4.0^{\star}$ & $1570 *$ \\
\hline 43 & 10,000 & 72.0 & 10 & $1.5^{\star}$ & $1340^{*}$ \\
\hline 46 & 10,000 & 72.0 & 10 & 0.75 & 1310 \\
\hline 44 & 10,000 & 72.0 & 10 & 0.40 & 1290 \\
\hline 45 & 10,000 & 72.0 & 10 & 0.20 & 1250 \\
\hline 81 & 12,500 & 89.9 & 10 & 0.61 * & $1130 *$ \\
\hline 42 & 13,500 & 97.2 & 10 & $0.9 *$ & $1030^{*}$ \\
\hline 76 & 14,300 & 103.0 & 10 & $0.65^{\star}$ & $830 *$ \\
\hline 75 & 15,350 & 110.5 & 10 & $0.39 *$ & $490 *$ \\
\hline 74 & 15,800 & 113.8 & 10 & $0.43^{\star}$ & $490 *$ \\
\hline 37 & 180 & 1.30 & 200 & 0.22 & 2500 \\
\hline & 180 & 1.30 & 200 & $0.4 *$ & $2510^{\star}$ \\
\hline 73 & 1,000 & 7.20 & 200 & $4.3^{\star}$ & $2260 *$ \\
\hline 38 & 1,000 & 7.20 & 200 & 0.5 & 2115 \\
\hline & 1,000 & 7.20 & 200 & $3.3^{\star}$ & 2150 * \\
\hline 39 & 1,000 & 7.20 & 200 & 0.2 & 1910 \\
\hline 70 & 2,500 & 18.0 & 200 & $4.3^{\star}$ & 1960 * \\
\hline 65 & 2,500 & 18.0 & 200 & $4.3^{\star}$ & 1930 * \\
\hline 35 & 2,500 & 18.0 & 200 & 2.2 & 1870 \\
\hline & 2,500 & 18.0 & 200 & $3.8 *$ & $1935^{\star}$ \\
\hline 71 & 4,000 & 28.8 & 200 & $3.7 *$ & $1850 \star$ \\
\hline 61 & 4,000 & 28.8 & 200 & $3.4^{\star}$ & $1835^{\star}$ \\
\hline 78 & 4,100 & 29.5 & 200 & $2.7^{\star}$ & $1790 *$ \\
\hline 36 & 6,000 & 43.2 & 200 & 1.0 & 1660 \\
\hline & 6,000 & 43.2 & 200 & $1.9 *$ & $1680^{*}$ \\
\hline 72 & 6,000 & 43.2 & 200 & $2.3^{\star}$ & $1635^{\star}$ \\
\hline 55 & 10,000 & 72.0 & 200 & 0.3 & 1390 \\
\hline & 10,000 & 72.0 & 200 & $0.9^{\star}$ & $1420 *$ \\
\hline 57 & 10,000 & 72.0 & 200 & 0.2 & 1300 \\
\hline 79 & 12,100 & 87.1 & 200 & $0.43^{\star}$ & $1200 *$ \\
\hline 40 & 13,500 & 97.2 & 200 & 0.25 & 1070 \\
\hline & 13,500 & 97.2 & 200 & $0.7^{\star}$ & $1115^{\star}$ \\
\hline 77 & 14,200 & 102.5 & 200 & $0.48^{\star}$ & $830 *$ \\
\hline
\end{tabular}

*Indicates failure ductility and tempera*ime for specimen which failed. 


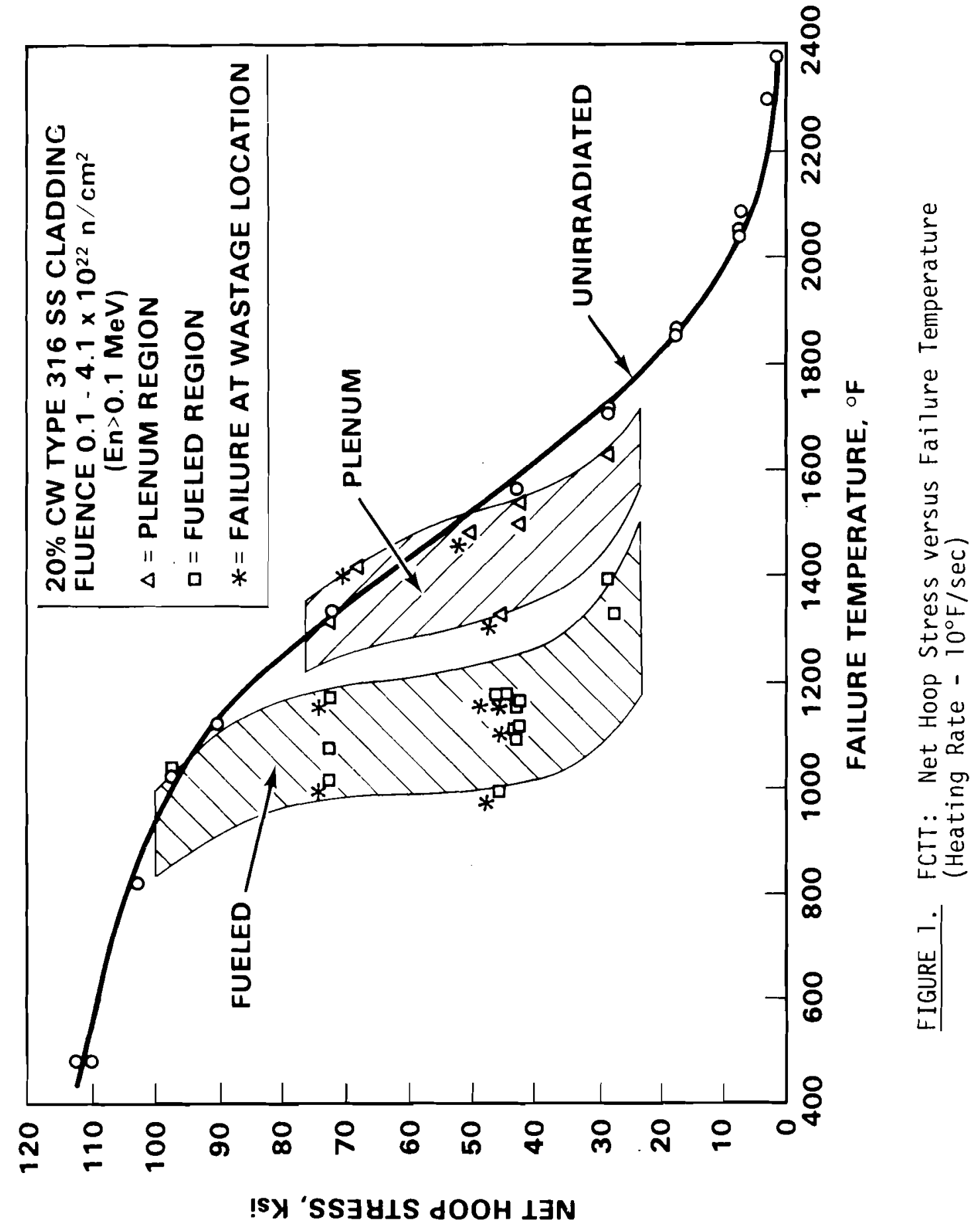




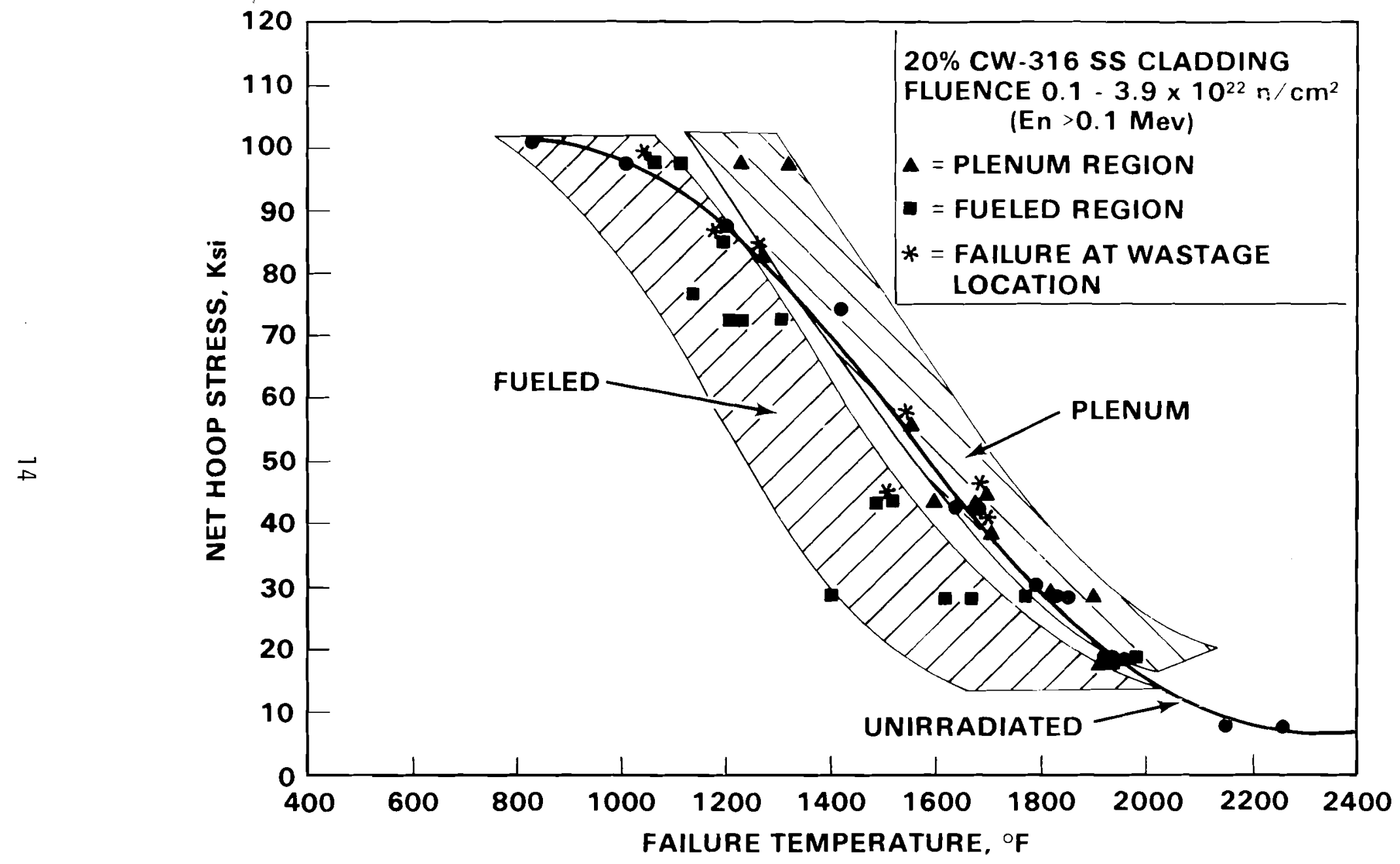

FIGURE 2. FCTT: Net Hoop Stress versus Failure Temperature (Heating Rate $=200^{\circ} \mathrm{F} / \mathrm{sec}$ ) 


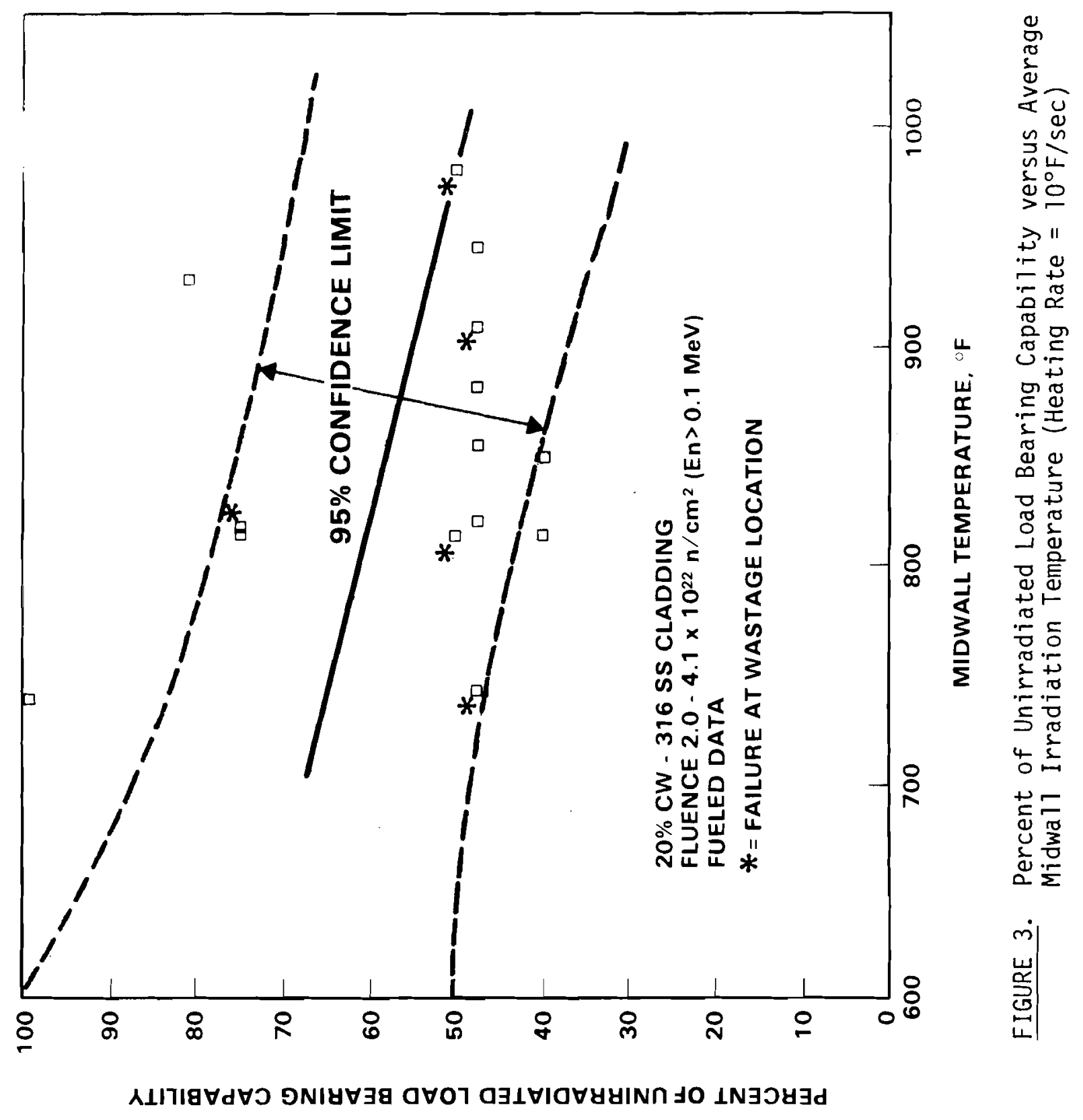




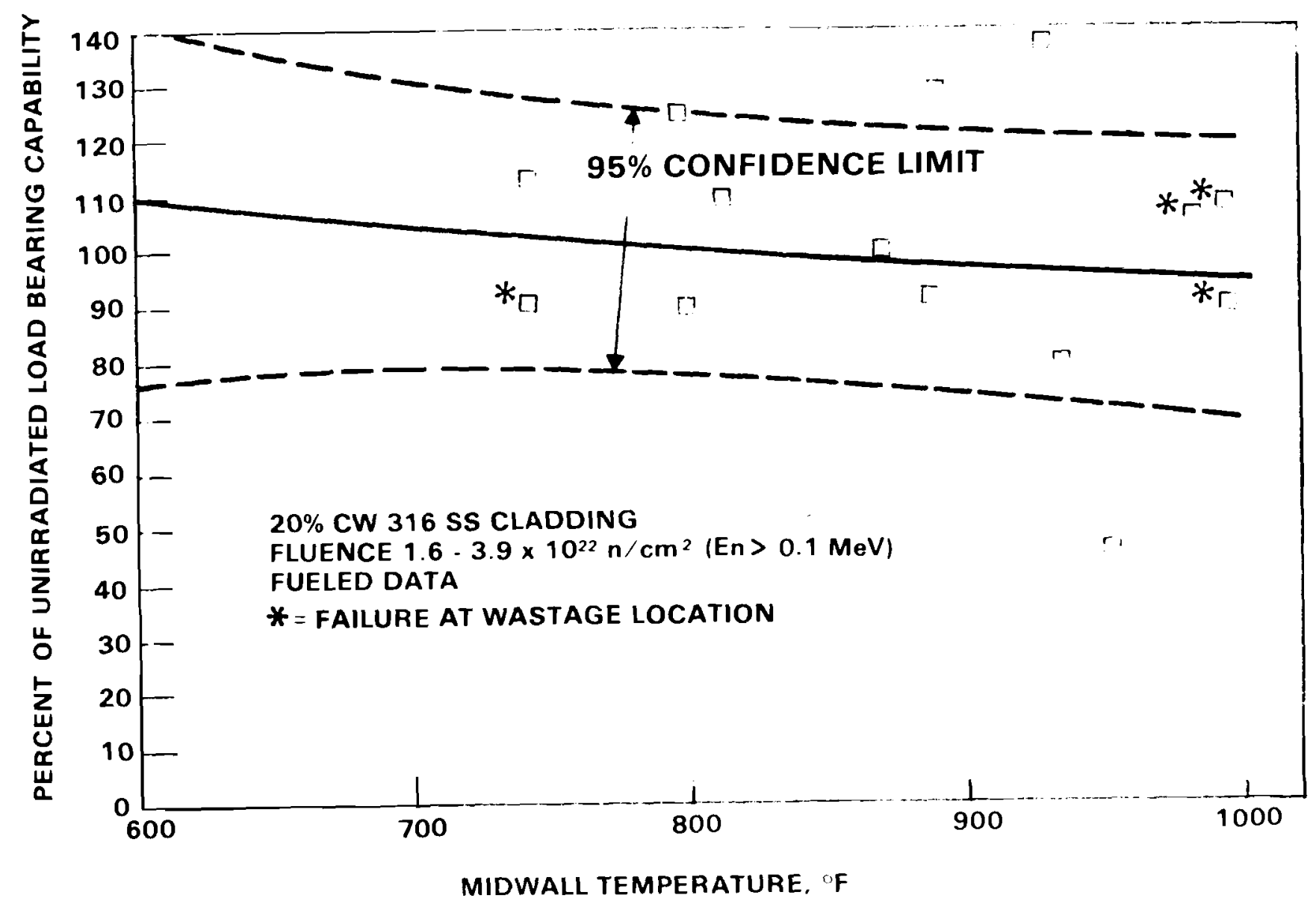

FIGURE 4. Percent of Unirradiated Load Bearing Capability versus Average Midwall Irradiation Temperature (Heating Rate $=200^{\circ} \mathrm{F} / \mathrm{sec}$ ) 


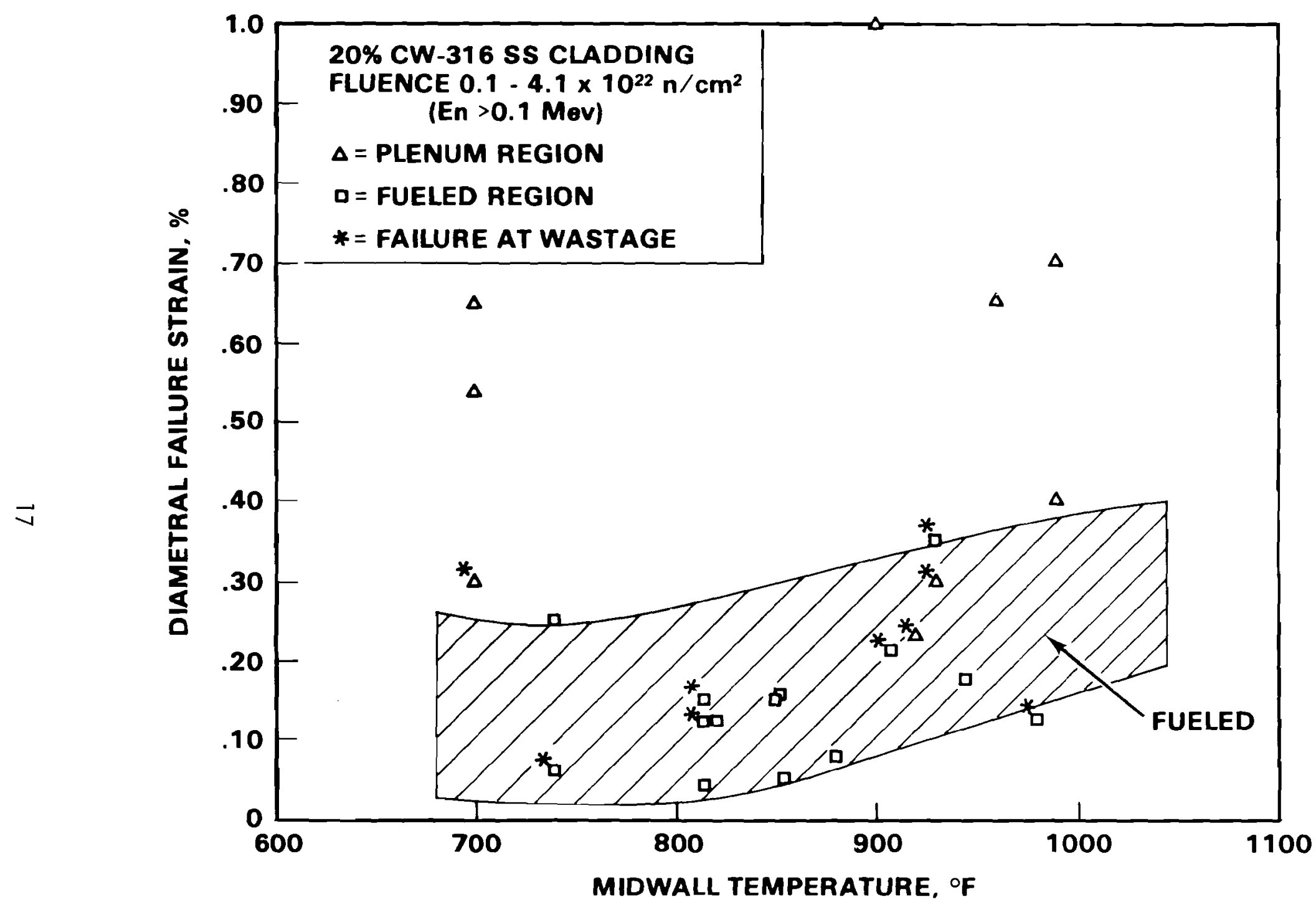

FIGURE 5. FCTT: Failure Strain versus Average Midwall Irradiation Temperature (Heating Rate $=10^{\circ} \mathrm{F} / \mathrm{sec}$ ) 


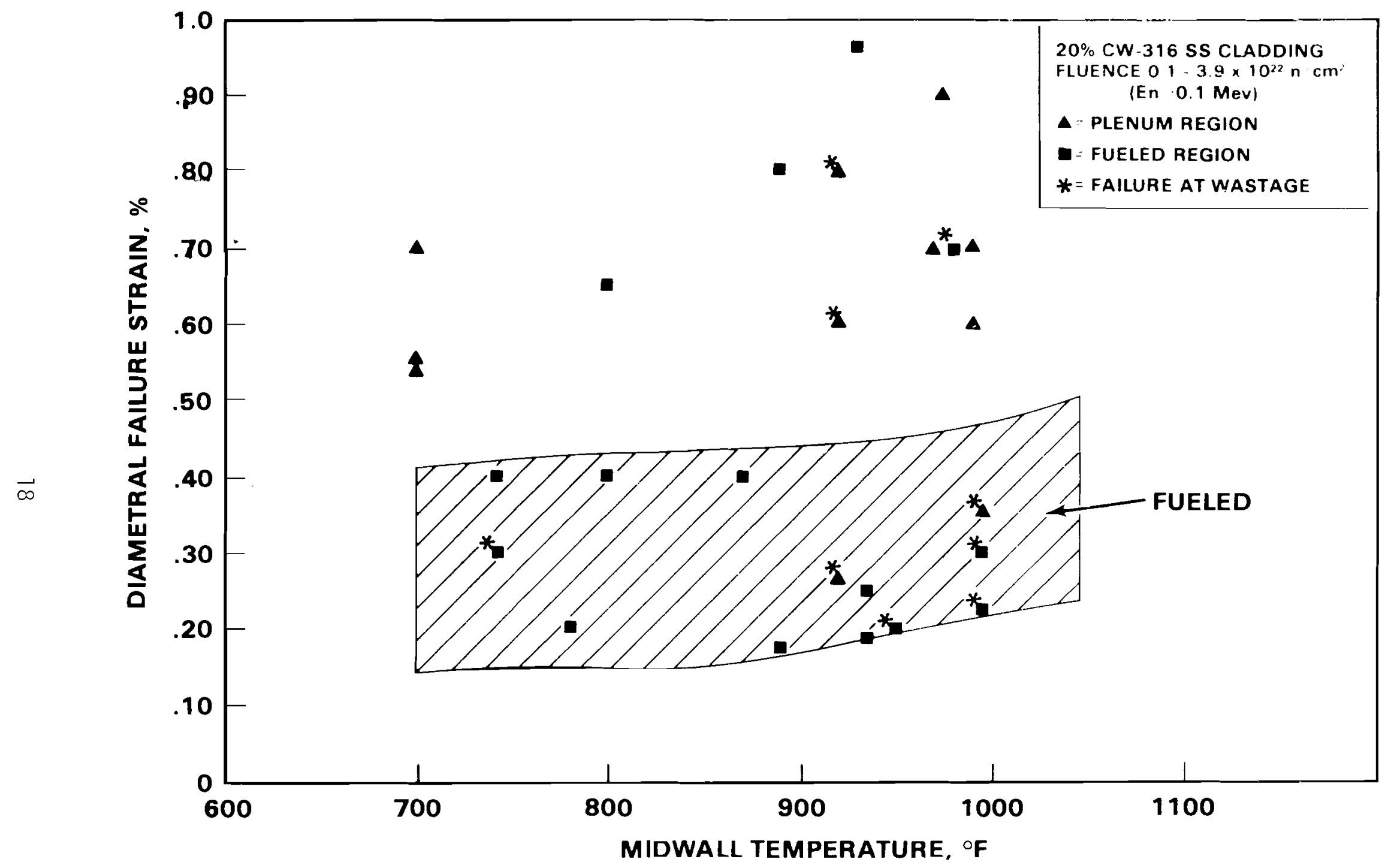

FIGURE 6. FCTT: Failure Strain versus Average Midwall

Irradiation Temperature (Heating Rate $=200^{\circ} \mathrm{F} / \mathrm{sec}$ ) 


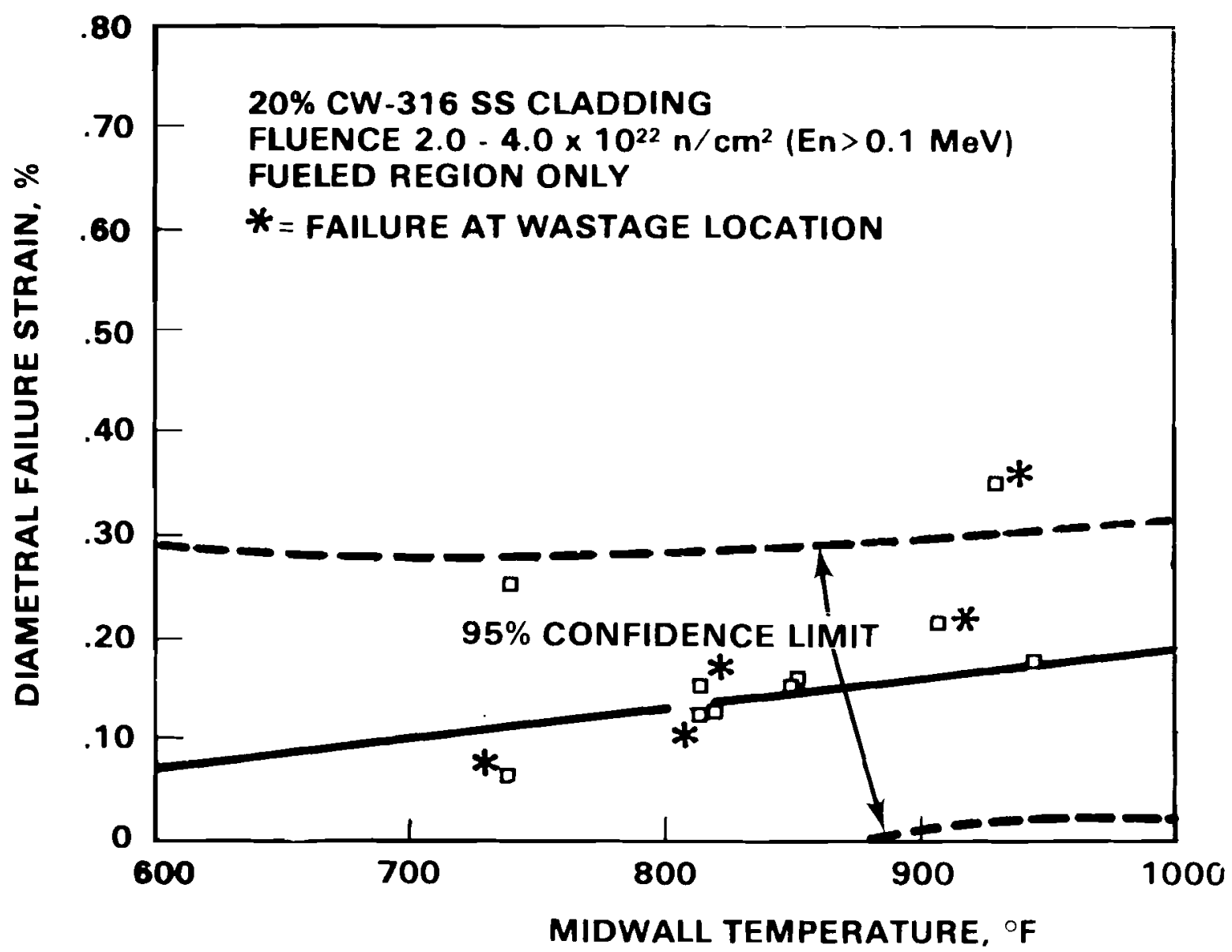

FIGURE 7. Data Statistics Relative to Design Criteria Failure Strain versus Average Midwal1 Irradiation Temperature (Heating Rate $=10^{\circ} \mathrm{F} / \mathrm{sec}$ ) 


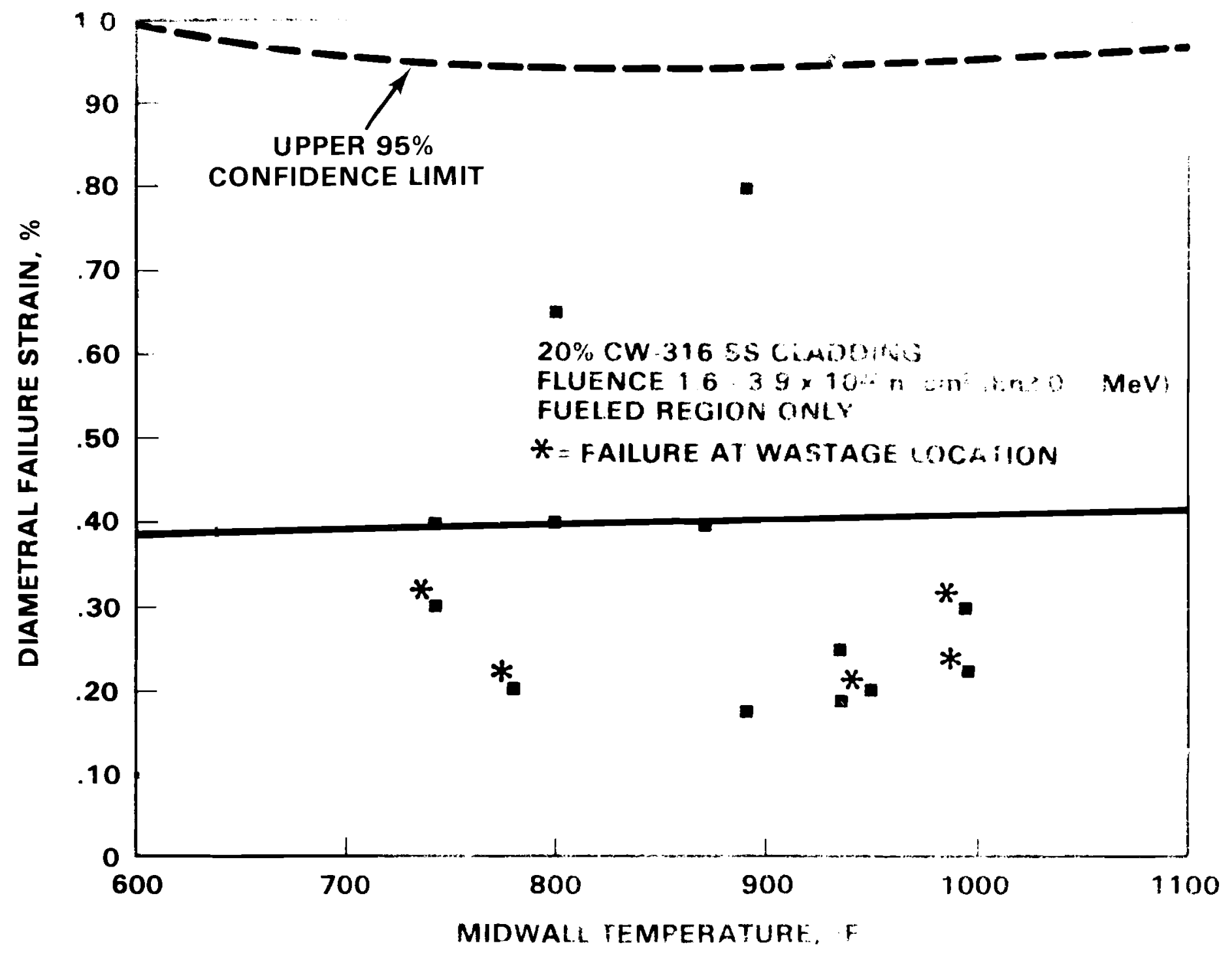

FIGURE 8. Data Statistics Relative to Design Criteria Failure Strain versus Average Midwall Irradiation Temperature (Heating Rate $=20^{\circ} \mathrm{F} / \mathrm{sec}$ ) 
BNWL -2041

$\mathrm{NRC}-1$

\section{DISTRIBUTION}

No. of

Copies

Offsite

A. A. Churm

ERDA Chicago Patent Group

9800 South Cass Avenue

Argonne, IL 60439

R. Denise, Assistant Director for Special Projects

Nuclear Regulatory Commission

Division of Project

Management

Washington, DC 20555

Mary Jinks

Public Reading Room

2 T. Speis, Chief LMFBR Branch

Nuclear Regulatory Commission

Division of Project

Management

Washington, DC 20555

2 J. Meyers, LMFBR Branch

Nuclear Regulatory Commission Division of Project

Management

Washington, DC 20555

2 P. Check, Chief Core Performance Branch

Nuclear Regulatory Commission Division of Systems Safety Washington, DC 20555

2 M. Tokar, Core Perfornance Branch

Nuclear Regulatory Commission Division of Systems Safety Washington, DC 20555
No. of

Copies

2 R. Meyer, Core Performance Branch

Nuclear Regulatory Commission

Division of Systems Safety

Washington, DC 20555

2 ERDA Technical Information Center

27 ERDA Technical Information Center for NRC Distribution 1

Onsite

ERDA Richland Operations Office

P.F.X. Durigan, Jr.

Westinghouse-Hanford Company

C.W. Hunter

J.E. Hanson

30 Battelle-Northwest

T.D. Chikala

P.D. Cohn

S. Goldsmith

R.S. Kemper

R.P. Marshall

I.S. Levy (14)

N.J. 01 son

F.E. Panisko

J.W. Wald (5)

Technical Information Files (3)

Technical Publications (BH) 